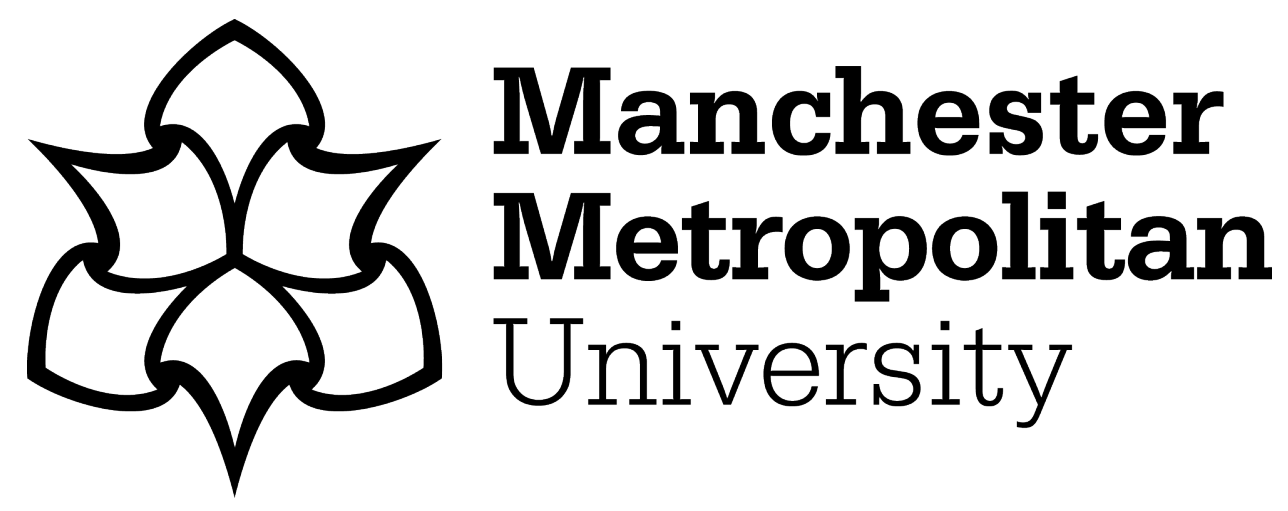

Giovanis, Eleftherios (2014) The Turn-of-the-Month-Effect: Evidence from Periodic Generalized Autoregressive Conditional Heteroskedasticity (PGARCH) Model. International Journal of Economic Sciences and Applied Research (IJESAR), 7 (3). pp. 43-61. ISSN 2408-0098

Downloaded from: https://e-space.mmu.ac.uk/620963/

Version: Published Version

Publisher: IJBESAR

Usage rights: Creative Commons: Attribution 3.0

Please cite the published version 


\title{
The Turn-of-the-Month-Effect: Evidence from Periodic Generalized Autoregressive Conditional Heteroskedasticity (PGARCH) Model
}

\author{
Eleftherios Giovanis ${ }^{1,2}$
}

\begin{abstract}
The current study examines the turn of the month effect on stock returns in 20 countries. This will allow us to explore whether the seasonal patterns usually found in global data; America, Australia, Europe and Asia. Ordinary Least Squares (OLS) is problematic as it leads to unreliable estimations; because of the autocorrelation and Autoregressive Conditional Heteroskedasticity (ARCH) effects existence. For this reason Generalized GARCH models are estimated. Two approaches are followed. The first is the symmetric Generalized ARCH $(1,1)$ model. However, previous studies found that volatility tends to increase more when the stock market index decreases than when the stock market index increases by the same amount. In addition there is higher seasonality in volatility rather on average returns. For this reason the Periodic-GARCH $(1,1)$ is estimated. The findings support the persistence of the specific calendar effect in 19 out of 20 countries examined.
\end{abstract}

Keywords: Calendar Effects, GARCH, Periodic-GARCH, Stock Returns, Turn of the Month Effect

JEL Classification: C22, G14

\section{Introduction}

Seasonal variations in production and sales of goods are a well known fact in business and economics. Seasonality refers to regular and repetitive fluctuation in a time series which occurs periodically over a span of less than a year. Similarly, stock returns exhibits systematic patterns at certain times of the day, week or month. The existence of seasonality in stock returns however violates an important hypothesis in finance that is efficient market hypothesis.

Capital market efficiency has been a very popular topic for empirical research since Fama (1970) introduced the theoretical analysis of market efficiency and proclaimed the Efficient Market Hypotheses (EMH). Subsequently, a great deal of research was devoted to

1 University of Bologna, Department of Economics, Via Tanari Vecchia 9-2, 40121, Bologna, Italy. giovanis95@gmail.com, Eleftherios.Giovanis.2010@live.rhul.ac.uk

2 Royal Holloway University of London, Department of Economics 
investigating the randomness of stock price movements for the purpose of demonstrating the efficiency of capital markets. Since then, all kinds of calendar anomalies in stock market return have been documented extensively in the finance literature. The most common calendar effects are the day of the week and the month of the year effect. However a curious anomaly, the turn of the month effect, has been found, which has been firstly documented by Ariel (1987). He examined the US stock returns and found that the mean return for stock is positive only for days immediately before and during the first half of calendar months, and indistinguishable from zero for days during the second half of the month.

The purpose of this paper is to investigate the turn of the month effect in stock market indices around the globe and to test its pattern, which can be used for the optimum asset allocation with result the maximization of profits. Because each stock market behaves differently and presents different turn of the month effect patterns, the trading strategy should be formed in this way where the buy and sell signals and actions will be varied in each stock market index. Haugen and Jorion (1996) suggested that calendar effects should not be long lasting, as market participants can learn from past experience. Hence, if the turn of the month effect exists, trading based on exploiting this calendar anomaly pattern of returns should yield extraordinary profits - at least for a short time. Yet such trading strategies affect the market in that further profits should not be possible: the calendar effect should break down.

The majority of the studies examining the turn of the month effect use as main tools statistical, from parametric and non parametric, test hypotheses to conventional econometric approaches and regression models, as ordinary least squares and symmetric GARCH estimations. To my knowledge this is the first study where the Periodic Generalized Autoregressive Conditional Heteroskedasticity (PGARCH) model for the turn of the month effect is employed.

The remainder of the paper has as follows: Section 2 discusses the literature review; in section 3 the methodology is described and section 4 presents the data sample and reports the summary statistics. Section 5 reports the results, while section six discusses the concluding remarks.

\section{Literature Review}

Many researchers studied the turn of the month effect. One of the first studies is by Ariel (1987), who obtained daily data for Center for Research in Security Prices (CRSP) value-weighted and equally-weighted stock index returns from 1963 through 1981. Ariel (1987), using descriptive statistics, finds that there are positive returns for the period starting on the last trading day of the previous month through the first half of the next month, followed by negative returns after the mid-point of the month. Also Ariel (1987) considers the January effect and he finds that for both indexes the means of both the first and the last nine trading days are lower when January is excluded from the analysis. Cadsby and Ratner (1992) examined stock market indices in ten countries-CRSP value-weighted and equally-weighted stock index returns for USA, Toronto stock exchange equally-weighted 
for Canada, Nikkei index for Japan, Hang Seng for Hong Kong, Financial times 500 share or UK, All ordinaries index for Australia, Banca Commerciale index for Italy, Swiss Bank Corporation Industrial index for Switzerland, the Commerzbank index for west Germany and the Compagnie des Agents de Change General Index for France. The dates vary in each index covering the period 1962-1989. Cadsby and Ratner (1992) define the turn-ofthe-month effect as the last and the first three trading days of each month. Daily returns are regressed on a constant and on a dummy variable, which equals at one for the turnof-the month days and zero for the other days, using ordinary least squares approach. The coefficient of the dummy variable is statistically higher than zero at $1 \%$ level for both value-weighted and equally-weighted stock indices of U.S.A. Also they reject the null hypothesis for Canada, Switzerland and West Germany at the same significance level. The same coefficient is statistically higher than zero at 5\% level for United Kingdom and Australia. However Cadsby and Ratner (1992) accept the null hypothesis for Japan, Hong Kong, Italy and France.

Jaffe and Westerfield (1989) obtain daily returns of stock market indices for four countries. The specific indices and the periods they examine are Financial Times Ordinary Share Index from January 2, 1950 to November 30, 1983 for UK; Nikkei Dow from January 5, 1970 to April 30, 1983 for Japan; Toronto Stock Exchange Index from January 2, 1977 to November 30, 1953 for Canada; and Statex-Actuaries Index from January 1, 1973 to April 30,1985 for Australia. They apply $t$-statistics to test whether there is significant difference between the intervals $[-9,-2]$ and $[-1,+9]$, where +1 denotes the first trading day of each month and -1 denotes the last trading day of each month. The results are mixed as authors find that there are higher returns of the first half of the month than returns of the last half of the month for Canada, Australia and United Kingdom. Jaffe and Westerfield (1989) change the intervals to $[-10,-2]$ and $[-1,+8]$ and they found positive significant returns only for Australia, while positive returns are observed for Canada and United Kingdom; however are statistically insignificant. The mean returns in the second half of the month are higher than the first half for Japan and are significant at 1\% level, suggesting a reverse monthly effect. Finally, Jaffe and Westerfield (1989) estimated a model using as dependent variable the daily returns of stock indices and independent variable a dummy, which takes value one during the first trading days and the last trading day of each month and zero otherwise. The coefficient of dummy variable is significant and positive for Canada, Australia and United Kingdom, while is significant and negative for Japan. Ziemba (1991) examines daily returns for NSA Japan during 1949-1988 for the intervals $[-5,+2]$ and $[-5,+7]$ and applying descriptive and $t$-statistics finds that in these intervals returns are higher than any other period. Finally, when the January effect is considered for the turn-of-the year effects, this effect starts on day -7 and it has positive returns on every trading day until day +14 .

McConnell and $\mathrm{Xu}$ (2008) examine the turn-of-the month effect for (CRSP) valueweighted and equally-weighted stock index returns in USA obtaining daily data during period 1926-2005. In addition, they examine the same effect using two sub-periods, 19261986 and 1987-2005. Also they test the turn-of-the month effect for other 34 countries McConnell and $\mathrm{Xu}(2008)$ define the turn-of-the month interval as $[-1,+3]$ and they found 
that the specific calendar effect exists for USA and for other 30 out of 34 countries except Argentina, Colombia, Italy, and Malaysia. The methodology they follow is descriptive and they use $t$-statistics to test whether the mean accumulative returns in the turn-of-the month interval are significant positive and different from zero and higher than the mean cumulative returns in the rest days of each trading month.

Martikainen et al. (1995) used daily returns of Finnish Options Index from May 2, 1988 to October 14, 1993. They examined the interval $[-1,+4]$ as the turn-of-the month and they apply $t$-statistics to test if the mean returns of this interval are positive and significant different from zero. Martikainen et al. (1995) found that these positive and significant returns are observed in the interval $[-5,+5]$. Kunkel et al. (2003) used daily closing prices for 19 countries from August 1, 1988 to July 31, 2000 to examine the turn-of-the month effect, which is defined as the interval $[-1,+3]$. Kunkel et al. (2003) regress daily returns on 18 dummy variables, which for example dummy $\mathrm{D}_{-9}$ takes value one if returns correspond to trading day -9 , continuing through $\mathrm{D}_{9}$ which corresponds to trading day 9 . The method which is applied is ordinary least squares. Over the 4-day turn-of-the month interval, all countries have at least one positive and statistically different from zero return, while most of them have two to four positive and statistically different from zero returns. Six countries have negative returns during this 4-day turn-of-the month period; however none of these returns are statistically insignificant. Finally Kunkel et al. (2003) regressed daily returns on a constant and on a dummy, where the latter takes value one of returns are corresponding in the turn-of-the month effect $[-1,+3]$ interval and zero otherwise. The coefficients of this regression shows that there are positive mean returns in every country during the $[-1,+3]$ interval.

Nikkinen et al. (2007) used daily data of SP100 stock market and VIX volatility indices data from January 1995 to December 2003. In the study by Nikkinen et al. (2007) daily returns of SP100 are regressed on two dummies. The first dummy takes value one if returns refer on the interval $[-9,+9]$ and zero otherwise, while the second variable takes value one if returns refer on the remained days of the month and zero otherwise. Nikkinen et al. (2007) find that the turn-of-the month effect is strongest in the $[+1+3]$ interval. Aggarwal and Tandon (1994) obtained daily data for 18 countries. The turn-of-the month is defined as the interval $[-4,+4]$. Aggarwal and Tandon (1994) used $t$-statistics and they found that there are significantly higher returns in the $[-1,+3]$ interval in ten countries.

Lakonishok and Smidt (1988) used ninety year daily data of Dow Jones Industrial Average from January 4, 1897 through June 11, 1986. Lakonishok and Smidt (1988) use $t$-statistics to test the difference in the average returns between turn-of-the-month interval and non turn-of-the-month and they find that the turn-of-the month effect strongly exists in the $[-1,+3]$ interval. Marquering, et al. (2006) used daily and monthly data of Dow Jones Industrial Average (DJIA) during period 1960-2003, with two sub-periods of estimation; 1960-1981 and 1982-2003. Marquering, et al. (2006) found that the turn-of-the-month effect still exists, while the other calendar effects, including the day of the week and the month of the year effect, disappear. Tonchev and Kim (2004) used daily values PX-50 and PX-D Indices of Czech Republic, the SAX Index for Slovakia and the SBI-20 and SBI- 
20NT indices for Slovenia. The periods are 1 January 1999- 18 June 2003 for the Czech Republic and 4 July 2000- 18 June 2003 for Slovakia. Tonchev and Kim (2004) studied the day-of-the week, January, turn-of-the month, the half month and holiday effects. Tonchev and $\operatorname{Kim}$ (2004) regressed the daily returns on six dummies where dummy $\mathrm{D}_{-3}$ is equal with one if returns correspond to the trading day -3 , continuing through up to $\mathrm{D}_{3}$, which is equal with one if returns correspond to the trading day 3 . All models are estimated with OLS and GARCH(1,1). Tonchev and Kim (2004) found that the turn-of-the-month effect does not exist. Giovanis (2009) examined the turn of the month effect in 55 stock market indices using bootstrapping t-statistics, concluding that the turn of the month effects is present in 36 indices. Georgantopoulos and Tsamis (2014) examined various calendar anomalies, including the turn-of-the-month effect, in stock returns on Istanbul Stock Exchange (ISE) over an eight years period (4/1/2000 - 4/1/2008) by Ordinary Least Squares (OLS) and Generalized Autoregressive Conditional Heteroskedasticity (GARCH 1,1) models. Testing the presence of the turn of the month effect the authors found that this market anomaly is strongly present in the ISE.

Hansen and Lunde (2003) derived a test for calendar anomalies, which controls for the full space of possible calendar effects. The countries examined are: Denmark, France, Germany, Hong Kong, Italy, Japan, Norway, Sweden, Japan, UK, and USA. The authors investigated various calendar effects including the turn-of-the-month effect and they found significant calendar effects in most series examined. However, in recent years it seems that the calendar effects have diminished, while most robust significance is found for small-cap stock indices, where calendar effects are generally found to be significant, across countries and subsamples. Zwergel (2014) examined the turn of the month effect using the indices; Germany (DAX), Japan (Nikkei 225), UK (FTSE 100) and US (S\&P 500) during the period January 1991 and November 2005. Zwergel (2014) argues that the turn of the month effect seems to be exploitable by using a futures trading strategy, even after transaction costs and slippage deductions due to the fact that turn of the month effect is quite volatile and that the liquidity at the close trades are assumed to be executed, is too low for institutional investors. Thus, the investors they would probably be paying higher prices than the closing prices when opening a long position and receiving lower prices when closing the position. Sharma and Narayan (2014) examined whether the turn-of-the-month affects firm returns and firm return volatility differently depending on their sector and size. Using 560 firms listed on the NYSE Sharma and Narayan (2014) found evidence that the turn-of-the-month affects returns and return volatility of firms. However, these effects depend on firm location and size.

On the other hand, other studies examine additional factors having impact on stock returns. A study by Vazakidis and Athianos (2010) examines the reaction of the Athens Stock Exchange (ASE) to dividend announcements by a sample of firms listed at the FTSE/ ATHEX 20 and FTSE/ATHEX Mid 40 for a fixed period 2004-2008, before and after the day of the announcement (event day). The authors test the hypotheses that there is no significant abnormal activity by the stock prices during the examined period and thus, the irrelevance theory introduced by Miller and Modigliani (1961) stands true. Using various 
event windows, no longer than 20 days, Vazakidis and Athianos (2010) reject the irrelevance theory and the hypothesis of no abnormal stock returns. Çağlı et al. (2011) examined the volatility shifts and persistence in variance using data for the sector indices of Istanbul Stock Exchange market. The authors extended the exponential generalized autoregressive conditional heteroskedasticity (EGARCH) model, proposed by Nelson (1991), by taking account of the volatility shifts which are determined by using iterated cumulative sums

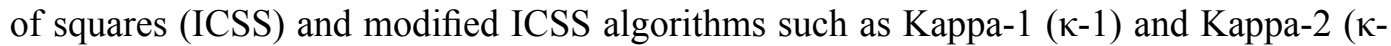
2). Their findings support that the inclusion of volatility shifts in the model substantially reduces volatility persistence and suggest that the sudden shifts in volatility should not be ignored in modelling volatility for Turkish sector indices.

Sariannidis (2010) using Generalized Autoregressive Conditional Heteroskedasticity $(\mathrm{GARCH})$ models examined the effects of capital and energy markets returns and exchange rate of the U.S. Dollar/ Yen on sugar features. More specifically, Sariannidis (2010) examines crude oil, Ethanol, SP500 and exchange rate of the U.S. Dollar/ Yen and he found that the higher energy prices, Crude oil and Ethanol, positively influence the sugar market, while the effects of U.S. Dollar/ Yen are negative on sugar market. Therefore, this study is suggested for future research as the calendar effects can be influenced by additional macroeconomic factors.

In recent years, there has been considerable interest in the autoregressive conditional heteroskedasticity (ARCH) disturbance model introduced by Engle (1982). Since their introduction, the ARCH model and its various generalizations, especially the generalized ARCH (GARCH) model introduced by Bollerslev (1986), have been particularly popular and useful in modelling the disturbance behaviour of the regression models of monetary and financial variables. Srinivasan and Ibrahim (2012) used a bivariate Error Correction Model Exponential GARCH (ECM-EGARCH) to examine the news effects from the spot exchange rates market to the volatility behaviour of futures market. Sariannidis et al. (2009) used the GARCH model to examine the relationship between Dow Jones Sustainability Index World (DJSI.-World) returns to 10 year bond returns and Yen/U.S. dollar exchange rate. An extensive survey of the theory and applications of these models is given by Bollerslev et al. (1992).

Previous studies found that seasonality in financial-market volatility is pervasive. Gallant et al. (1992) reported that the historical variance of the Standard and Poor's composite stock-price index in October is almost ten times the variance for March. Similarly, Bollerslev and Hodrick (1999) found evidence for significant seasonal patterns in the conditional heteroskedasticity of monthly stock-market dividend yields. Regarding daily frequency studies demonstrated that daily stock-return and foreign-exchange-rate volatility tend to be higher following non-trading days, although proportionally less than during the time period of the market closure (French and Roll, 1986; Baillie and Bollerslev, 1989). At the intraday level, Wood et al. (1985) found that the variances of stock returns over the course of the trading day present a U-shaped pattern. Similar patterns in the volatility of intraday foreign-exchange rates are reported in other studies (Baillie and Bollerslev, 1991; Harvey and Huang, 1991; Dacorogna et al., 1993). 


\section{Data and Methodology}

\subsection{Data and Summary Statistics}

The data are daily closed prices of stock market indices. The analysis is conducted in terms of daily returns which is defined as $r=\log \left(\mathrm{P}_{t} / \mathrm{P}_{\mathrm{t}-1}\right)$. More specifically, in Table 1 we present the countries and the indices symbols. The final period is 31 December 2013 for all series except from the starting period, where it is shown in Table 1.

In Table 2 the descriptive statistics for stock market indices returns in 10 countries are reported. In all cases mean returns are very low and in some countries are negative as in Italy and Taiwan. As it was expected leptokurtosis is observed in all stock returns, as the value of kurtosis is very high reaching even 99 in the case of Australia.

Heavy tails are commonly found in daily return distributions. Negative skewness is presented in all series expect from Brazil, Greece, Malaysia, and Mexico. In addition based on Jarque-Bera statistic and the probability it is concluded that the normality assumption in the time series examined is rejected, supporting the non-normal distribution of the stock index returns examined in this study. One can use median return instead of mean to represent returns. Based on median returns, Argentina and Brazil report the highest return followed by India and Indonesia. On the other hand, the lowest median returns are presented in Greece, followed by China and Taiwan.

Table 1: Stock Market Indices and estimating periods

\begin{tabular}{|c|c|c|c|}
\hline Countries & Period & Countries & Period \\
\hline $\begin{array}{l}\text { Argentina (MERVAL } \\
\text { INDEX) }\end{array}$ & 9 October 1996 & $\begin{array}{l}\text { Indonesia (JKSE } \\
\text { Composite Index) }\end{array}$ & 2 July 1997 \\
\hline $\begin{array}{c}\text { Australia (All } \\
\text { ordinaries Index) }\end{array}$ & 9 January 2001 & Italy (MIBTEL INDEX) & 2 January 1998 \\
\hline Austria (ATX INDEX) & 12 November 1992 & Japan (Nikkei 225) & 5 January 1984 \\
\hline $\begin{array}{l}\text { Brazil (IBOVESPA } \\
\text { INDEX) }\end{array}$ & 28 April 1993 & $\begin{array}{l}\text { Malaysia (KLSE } \\
\text { INDEX) }\end{array}$ & 6 December 1993 \\
\hline $\begin{array}{l}\text { China (Shanghai } \\
\text { composite Index) }\end{array}$ & 4 July 1997 & Mexico (IPC INDEX) & 11 November 1991 \\
\hline $\begin{array}{c}\text { France (CAC } 40 \\
\text { INDEX) } \\
\end{array}$ & 2 March 1990 & $\begin{array}{l}\text { Netherlands (AEX } \\
\text { INDEX) }\end{array}$ & 13 October 1990 \\
\hline $\begin{array}{c}\text { Germany } \\
\text { (DAX INDEX) }\end{array}$ & 27 November 1990 & Singapore (STI INDEX) & \\
\hline $\begin{array}{l}\text { Greece (GENERAL } \\
\text { INDEX) } \\
\text { www.enet.gr }\end{array}$ & 5 January 1998 & $\begin{array}{c}\text { Taiwan (TSEC weighted } \\
\text { index) }\end{array}$ & 3 July 1997 \\
\hline $\begin{array}{l}\text { Hong Kong (HANG } \\
\text { SENG INDEX) }\end{array}$ & 2 January 1987 & UK (FTSE-100) & 3 April 1984 \\
\hline India (BSE SENSEX) & 2 January 1997 & USA (S\&P 500) & 4 January 1950 \\
\hline
\end{tabular}




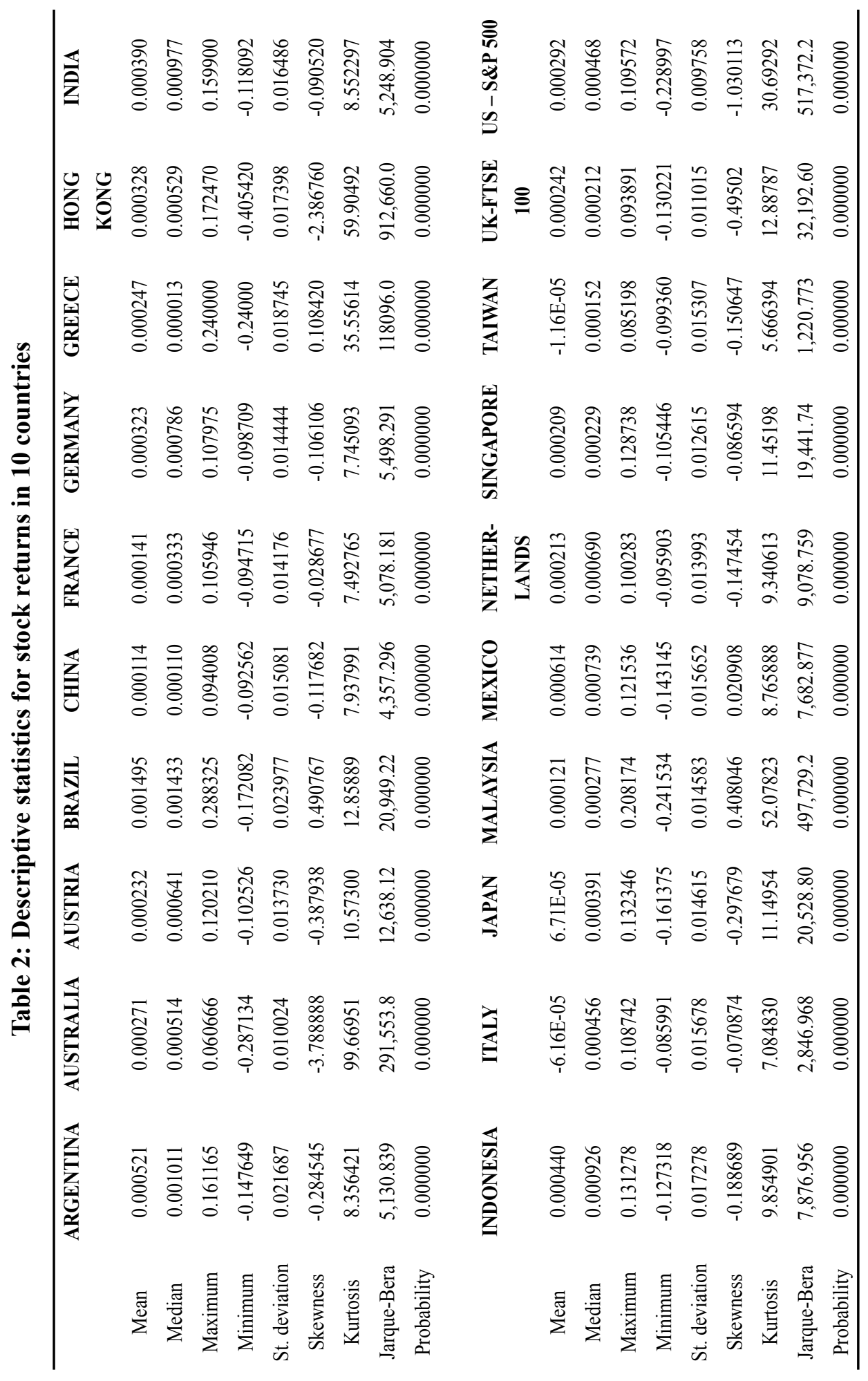




\subsection{Stationarity and Unit Root Tests}

In this section ADF test statistic (Dickey and Fuller, 1979) is applied in order to examine whether the stock returns examined in this study stock returns are stationary as it was expected. The ADF test can be defined by testing the following equation:

$$
\mathrm{R}_{\mathrm{t}}=\alpha+\delta \mathrm{t}+\varphi \mathrm{R}_{\mathrm{t}-1}+\text { lags of } \Delta \mathrm{R}_{\mathrm{t}}+\varepsilon_{\mathrm{t}}
$$

and the hypotheses we test are:

$$
\mathrm{H}_{0}: \varphi=1, \delta=0=>\mathrm{R}_{\mathrm{t}} \sim \mathrm{I}(0) \text { with drift }
$$

against the alternative

$$
\mathrm{H}_{1}:|\varphi|<1 \quad \Rightarrow>\mathrm{R}_{\mathrm{t}} \sim \mathrm{I}(1) \text { with deterministic time trend }
$$

In Table 3 the results of ADF test are reported. Based on the $t$-statistics, the stock returns are stationary. The stationarity is supported also based on additional tests, such as the Dickey-Fuller (DF), the Phillips-Perron (PP) and the Kwiatkowski-Phillips-SchmidtShin (KPSS) test.

Table 3: ADF test for stock returns in 20 countries

\begin{tabular}{|c|c|c|c|}
\hline Countries & Test ADF t-statistic & Countries & Test ADF t-statistic \\
\hline ARGENTINA & -51.362 & INDONESIA & -44.902 \\
\hline AUSTRALIA & -36.224 & ITALY & -48.408 \\
\hline AUSTRIA & -59.857 & JAPAN & -58.606 \\
\hline BRAZIL & -58.165 & MALAYSIA & -26.618 \\
\hline CHINA & -50.483 & MEXICO & -45.397 \\
\hline FRANCE & -68.537 & NETHERLANDS & -39.251 \\
\hline GERMANY & -67.875 & SINGAPORE & -44.335 \\
\hline GREECE & -27.667 & TAIWAN & -50.785 \\
\hline HONG KONG & -39.636 & UK-FTSE 100 & -39.451 \\
\hline INDIA & -49.398 & US - S\&P 500 & -86.604 \\
\hline
\end{tabular}

* MacKinnon critical values for rejection of hypothesis of a unit root at $1 \%, 5 \%$ and $10 \%$ are $-3.4786,-2.8824$ and -2.5778 respectively. 


\subsection{Symmetric GARCH Model}

The consequences of heteroskedasticity are problematic in general, and it is well known that the consequences of heteroskedasticity for OLS estimation are very serious. Although parameter estimates remain unbiased, they are no longer efficient, meaning they are no longer best linear unbiased estimators (BLUE) among the class of all the linear unbiased estimators. For this reason GARCH and PGARCH models are employed in this study to account for autocorrelation, heteroskedasticity and volatility clustering.

The turn-of-the month (TOM) effect is defined as the interval $[-1,+3]$, where -1 is the last trading day of each month and continuing until +3 , which is the third trading day of each month. The general form of a GARCH $(p, q)$ model, which was proposed by Bollerslev (1986) is:

$$
E\left[\varepsilon_{t} \mid \Omega_{t-1}\right]=\sigma_{t}^{2}=\omega+\sum_{i=1}^{p} a_{i} \varepsilon_{t-1}^{2}+\sum_{j=1}^{q} \alpha_{j} \sigma_{t-j}^{2}
$$

The GARCH $(1,1)$ model will be:

$$
\begin{gathered}
R_{t}=\beta_{0} D_{\mathrm{TOM}}+\beta_{1} D_{N \mathrm{TOM}}+\varepsilon_{t}, \quad \varepsilon_{t} \sim\left(0, \sigma^{2}\right) \\
\sigma_{t}^{2}=\omega+a_{1} u_{t-1}^{2}+a_{2} \sigma_{t-1}^{2}
\end{gathered}
$$

where (3) and (4) indicate the mean and the variance equations respectively. $R_{t}$ denotes the daily stock returns, $D_{\text {TOM }}$ is a dummy variable obtaining value 1 for mean returns belonging in the TOM interval $[-1,+3]$ and 0 otherwise, $D_{\text {NTOM }}$ is a dummy variable obtaining value 1 for mean returns not belonging in the NTOM interval and 0 otherwise and $\varepsilon_{t}$ is the disturbance term. Based on the turn of the month effect, it is expected that the coefficient $\beta_{0}$ will be significant positive and higher than coefficient $\beta_{l}$. Alternatively, it is expected that coefficient $\beta_{1}$ will be insignificant or negative.

Regarding the diagnostic tests, firstly ARCH effects are tested using the BreuschPagan Lagrange Multiplier (LM) test. To test for ARCH of order $\mathrm{p}$ the following auxiliary regression model is considered:

$$
\varepsilon_{t}^{2}=\gamma_{0}+\gamma_{1} \varepsilon_{t-1}^{2}+\gamma_{2} \varepsilon_{t-2}^{2}+\ldots \ldots+\gamma_{p} \varepsilon_{t-p}^{2}+\eta_{t}
$$

Under the null hypothesis of no ARCH,

$$
H_{0}=\gamma_{1}=\gamma_{2}=\ldots . .=\gamma_{p}=0
$$

The hypothesis can be tested using the familiar statistic:

$$
T \cdot R^{2} \rightarrow x^{2}(p)
$$

The second diagnostic test is the autocorrelation test on residuals. The Ljung-BoxPierce Q-statistic (Box and Pierce, 1970; Ljung and Box, 1978) is applied. 
Let $e(1), \ldots \ldots \ldots, e(n)$ be the standardized residuals from fitting a time series regression model, and let (34) be their autocorrelations.

$$
\hat{r}(k)=\frac{\sum_{t=k+1}^{n} \hat{e}(t) \hat{e}(t-k)}{\sum_{t=k+1}^{n} \hat{e^{2}}(t)}, \text { for } k=1,2, \ldots . n
$$

If the model is correct, the Ljung-Box-Pierce Q-statistic is:

$$
Q(\hat{r})=n(n+2) \sum_{k=1}^{m}(n-k)^{-1} \hat{r}(k)
$$

where (9) is asymptotically distributed as $x^{2}$ with $m-p$ degrees of freedom where $p$ denotes the number of parameters in the model. The null hypothesis is that there is no autocorrelation in the residuals. Various lags have been used; however for the ARCH LM test 5 lags have been used and for the autocorrelation test 12 lags.

\subsection{Periodic GARCH Model}

In this section the methodology of Periodic GARCH $(1,1)$ is provided, which have been proposed by Bollerslev and Chysels (1996). The class of P-GARCH processes may be defined as:

$$
E\left[\tilde{\varepsilon}_{t} \mid \Omega_{t-1}^{s}\right]=0
$$

where $s(t)$ refers to the stage of the periodic cycle at time $t$. The general form of PeriodicGARCH model is:

$$
E\left[\tilde{\varepsilon}_{t} \mid \Omega_{t-1}^{s}\right]=\tilde{\sigma}_{t}^{2}=\omega_{s(t)}+\sum_{i=1}^{q} a_{i s(t)} \tilde{\varepsilon}_{t-1}^{2}+\sum_{j=1}^{p} \alpha_{j s(t)} \tilde{\sigma}_{t-j}^{2}
$$

In this study the Periodic GARCH $(1,1)$ used for the turn-of-the month effect and regression (2) is the following:

$$
\sigma_{t}^{2}=\omega+a_{1} u_{t-1}^{2}+a_{2} \sigma_{t-1}^{2}+d_{s t} \omega_{s}+d_{s t} a_{1 s} u_{t-1}^{2}+d_{s t} a_{2 s} \sigma_{t-1}^{2}
$$

In the variance equation (12) the coefficients definition remain the same as in (4), with the difference that $d_{s t}$ equals with one if $s$ is the stage of the periodic cycle at time $t$ and $d_{s t}=0$ otherwise. More precisely stage of the periodic cycle $s$ is equal at 1 for days belonging in the TOM interval and 0 otherwise. 


\section{Empirical Results}

In Tables 4 and 5 the $\operatorname{GARCH}(1,1)$ and PGARCH$(1,1)$ estimates respectively are reported. Based on these results the coefficient $\beta_{0}$ is always positive, significant and higher than coefficient $\beta_{1}$ with the exception of Australia. Therefore the main conclusion is that the turn of the month effect is presented in 19 out of 20 stock market indices examined. The findings are consistent with other studies (Ariel, 1987; Cadsby and Ratner, 1992; Giovanis, 2009). The coefficient $\beta_{0}$ is always significant at $1 \%$ level, while in some cases coefficient $\beta_{1}$ is statistically insignificant. It should be noticed that different samples have been employed. More specifically, three samples have been used. Firstly, from the starting period of each stock market index up to 2007 before the financial crisis. The second sample is the period 2008-2009 and the third sample is from the starting period for each stock market index up to 2013. However, the results remain the same, only changing the magnitude of the coefficients around 1-2\%, and they are not presented due to space limitations. Nevertheless, the conclusion change only for Australia, where the turn of the month effect exists, using the first two samples, but not when the whole period is included in the analysis, obtaining also the post-financial crisis period 2010-2013.

Regarding the diagnostic tests PGARCH outperforms the GARCH model based on Log-Likelihood, on Akaike Information Criterion (AIC) and Schwarz Bayesian Criterion (SBC). In addition, in most cases the GARCH model solves for autocorrelation and ARCH effects. On the other hand, PGARCH solves for these problems in Mexico, as well as, in Netherlands for autocorrelation at $10 \%$. However, in some countries the problems still remain. More specifically, in Hong Kong both models do not solve for the autocorrelation and $\mathrm{ARCH}$ effects, in Netherlands for autocorrelation at 10\% and for ARCH effects at 5\% and $10 \%$ and in UK for ARCH effects at $10 \%$ level.

Moreover, the condition that $a_{1}+a_{2}<1$, holds. More precisely, this condition secures covariance stationarity of the conditional variance. A straightforward interpretation of the estimated coefficients in GARCH and PGARCH models is that the constant term $\omega$ is the long-term average volatility, i.e. conditional variance, whereas $\alpha_{1}$ and $a_{2}$ represent how volatility is affected by current and past information, respectively. Similarly, $\alpha_{1 s}$ and $a_{2 s}$ represent how volatility is affected in the periodic cycle examined, which is the turn of the month interval.

Generally, it should be noticed that various methodologies have been applied among the studies and researchers, who examined calendar anomalies in stock returns. Most of them apply descriptive statistics, OLS and GARCH models, while none of them examined the turn of the month effect using the PGARCH model. The results of this study confirm the findings by Marquering et al. (2006), who found that the turn-of-the-month is still persistent. Marquering et al. (2006) claim that the persistence of turn-of-the-month effect might be explained by the transaction costs, which are too high for the investors to profit from this calendar anomaly, as they cannot exploit the pattern. 


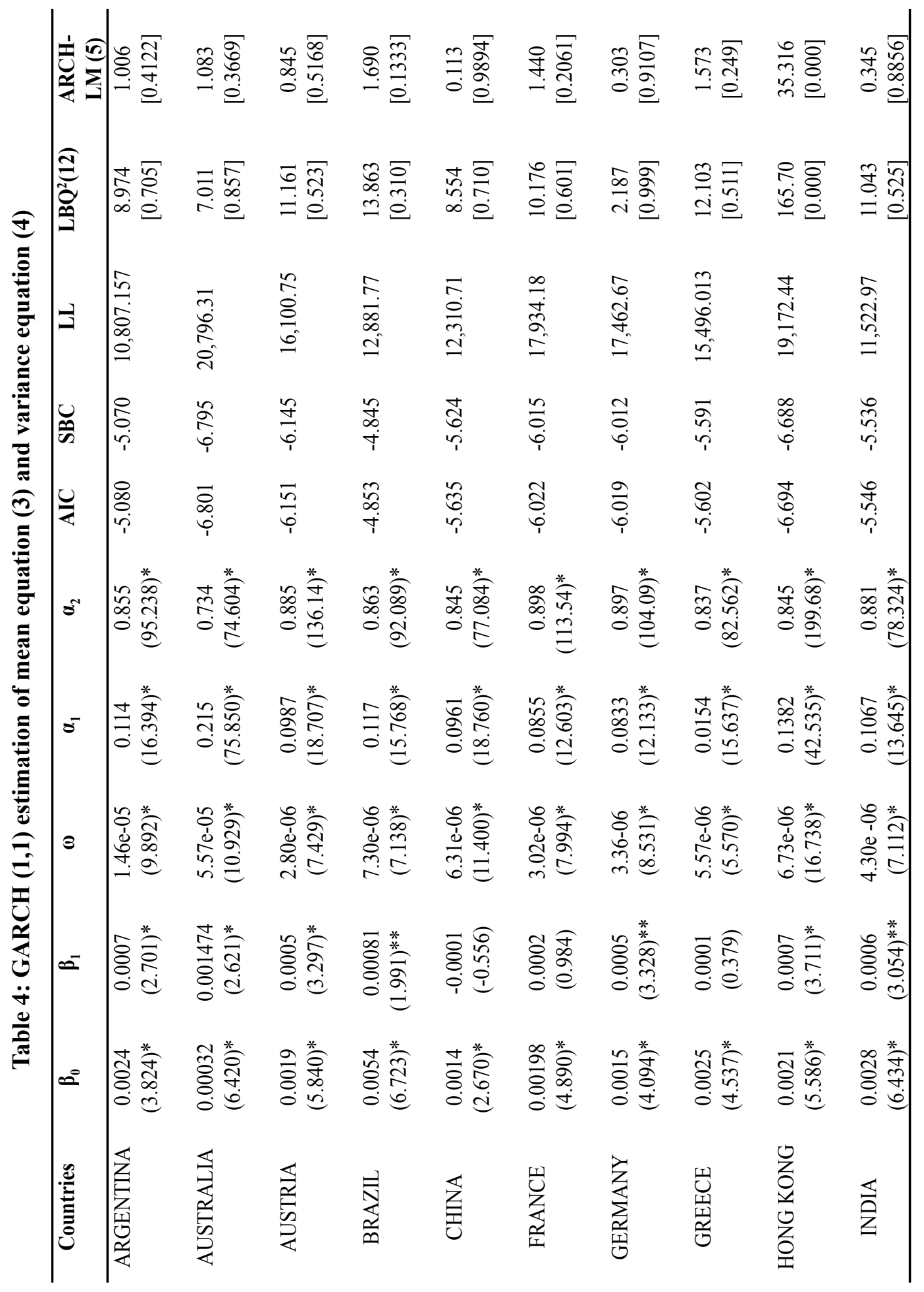




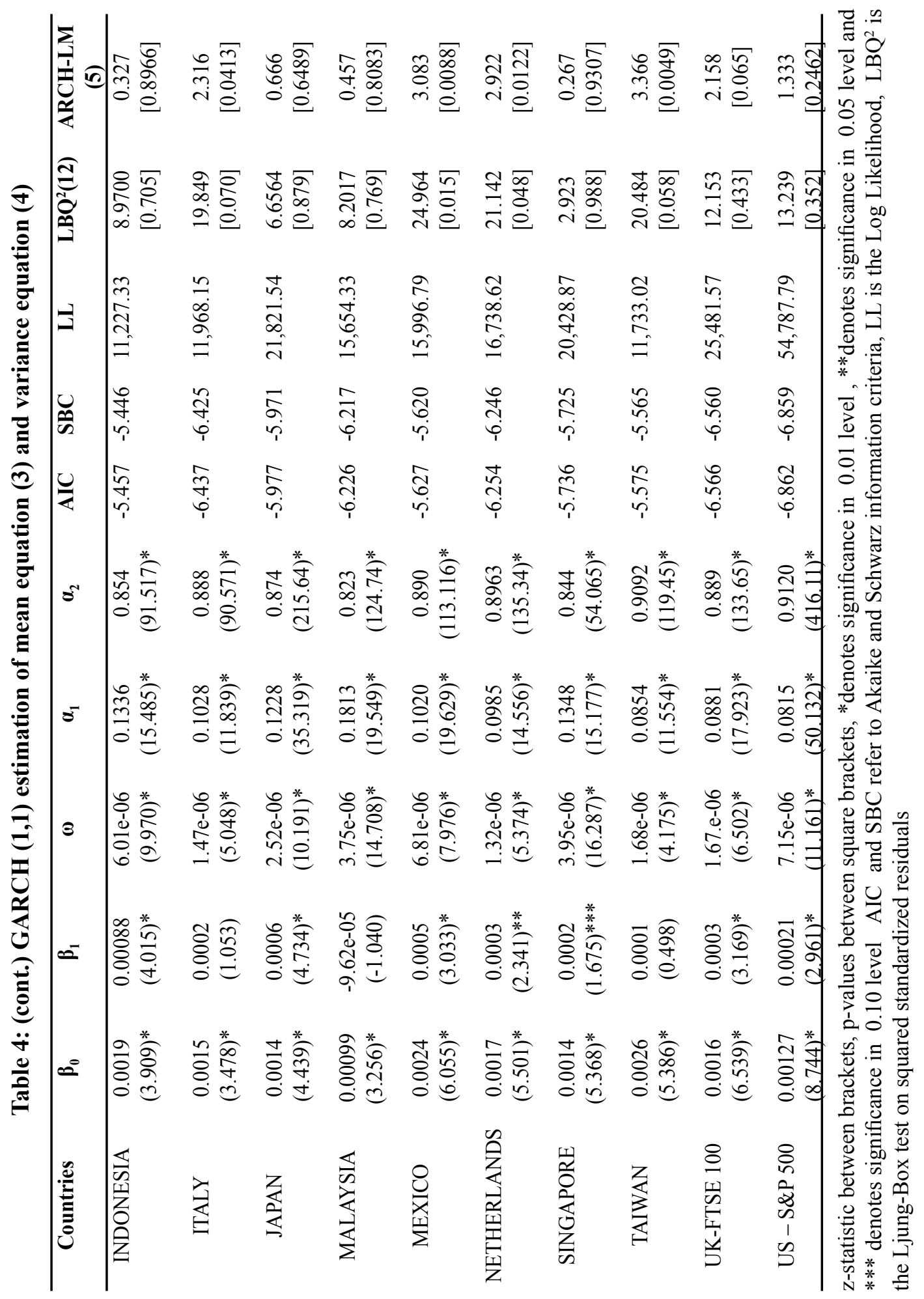




\begin{tabular}{|c|c|c|c|c|c|c|c|c|c|}
\hline$\sum_{\substack{1 \\
1}}$ & 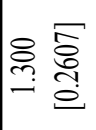 & 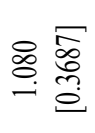 & 守 & 豆焉 & 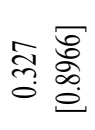 & $\begin{array}{l}\infty \\
\stackrel{\infty}{\approx} \\
= \\
ٍ\end{array}$ & 唀 $\frac{\pi}{\infty}$ & 尔 & 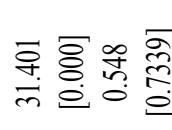 \\
\hline ర્ติ త & 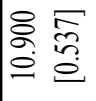 & 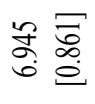 & 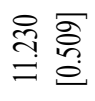 & $\begin{array}{l}\approx \\
\stackrel{n}{\varrho} \\
\infty\end{array}$ & $\begin{array}{l}\stackrel{5}{2} \\
\text { के } \\
\text { के }\end{array}$ & 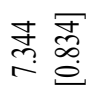 & बू & $\begin{array}{l}\sqrt{\circ} \widetilde{\sigma} \\
\infty \\
=0 \\
=\end{array}$ & 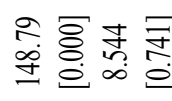 \\
\hline$\exists$ & 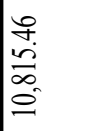 & 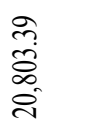 & \begin{tabular}{l}
$\tilde{2}$ \\
\multirow{0}{0}{} \\
0 \\
0
\end{tabular} & 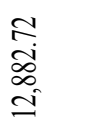 & 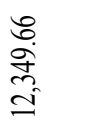 & $\begin{array}{l}\vec{z} \\
\tilde{n} \\
\Sigma\end{array}$ & 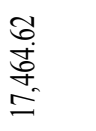 & 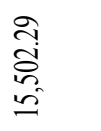 & 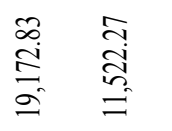 \\
\hline 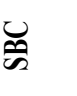 & $\begin{array}{l}\approx \\
0 \\
0 \\
i\end{array}$ & $\frac{\text { के }}{\frac{1}{6}}$ & $\frac{\text { 守 }}{\text { 审 }}$ & $\begin{array}{l}\tilde{Z} \\
\infty \\
\dot{y} \\
\dot{y}\end{array}$ & 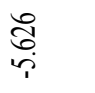 & $\stackrel{2}{0}$ & $\stackrel{n}{0}$ & कृ & 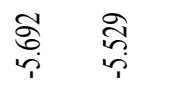 \\
\hline$\stackrel{\bigcup}{\varkappa}$ & $\frac{2}{2}$ & \begin{tabular}{l}
2 \\
$\infty$ \\
\hdashline \\
1
\end{tabular} & $\frac{n}{\stackrel{0}{\varphi}}$ & $\begin{array}{l}\overrightarrow{8} \\
\stackrel{0}{+}\end{array}$ & 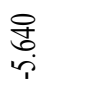 & 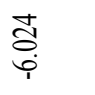 & ֻ̊ & $\begin{array}{l}\frac{7}{0} \\
\stackrel{?}{i}\end{array}$ & 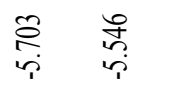 \\
\hline $8^{2}$ & 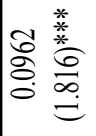 & $\begin{array}{l}\stackrel{\hat{\sigma}}{\hat{a}} \\
\dot{0}\end{array}$ & 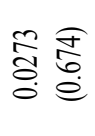 & 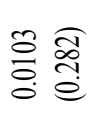 & 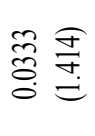 & 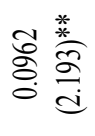 & 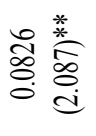 & 总 & 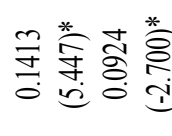 \\
\hline$\stackrel{\infty}{0}$ & 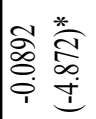 & 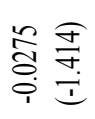 & 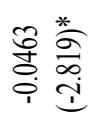 & 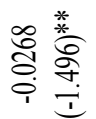 & 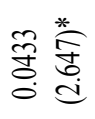 & 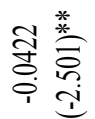 & 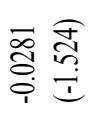 & 蒡 & 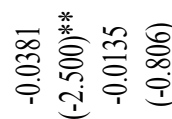 \\
\hline $3^{\infty}$ & 尊 & 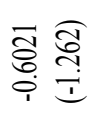 & 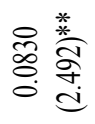 & $\begin{array}{l}\stackrel{0}{\circ} \\
\stackrel{\circ}{\circ} \stackrel{0}{0}\end{array}$ & 令 & 寻 实 & 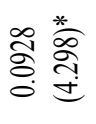 & 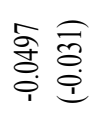 & 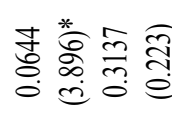 \\
\hline$\sigma^{r}$ & 索 & $\begin{array}{l}\frac{*}{\infty} \\
\frac{\sigma}{\sigma} \\
\sigma\end{array}$ & 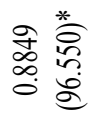 & 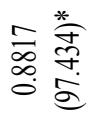 & 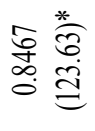 & $\begin{array}{l}2 \stackrel{*}{\stackrel{*}{\sigma}} \\
\infty \\
\infty \\
0\end{array}$ & 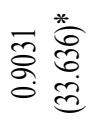 & 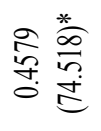 & 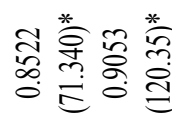 \\
\hline 5 & 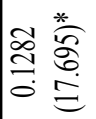 & 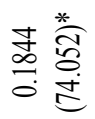 & 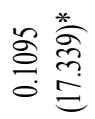 & 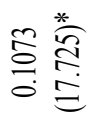 & 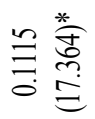 & 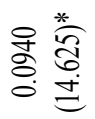 & 旁 & 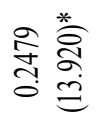 & 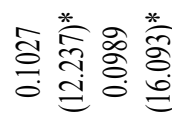 \\
\hline 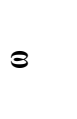 & 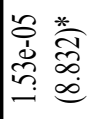 & 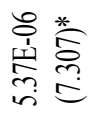 & 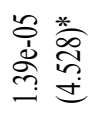 & 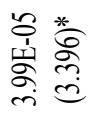 & 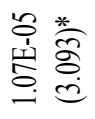 & 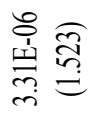 & 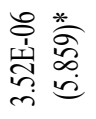 & 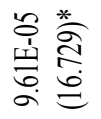 & 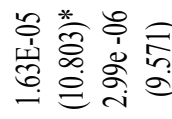 \\
\hline$\infty$ & 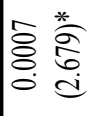 & 总总 & 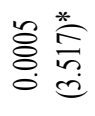 & 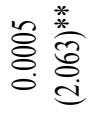 & 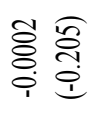 & 於 & 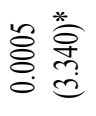 & 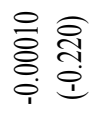 & 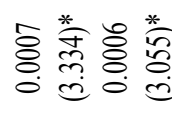 \\
\hline$\infty$ & 突 & 总总 & 产总 & 宣 & 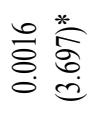 & 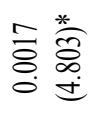 & 邑 & 总莣 & 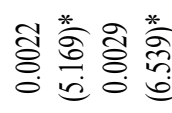 \\
\hline 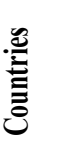 & 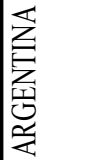 & 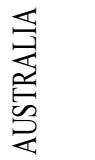 & 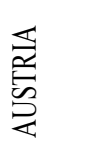 & 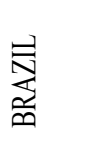 & 茎 & 岂 & $\sum_{\substack{\text { 空 } \\
\text { 究 }}}$ & 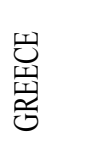 & $\begin{array}{l}0 \\
0 \\
0 \\
0 \\
0 \\
0\end{array}$ \\
\hline
\end{tabular}




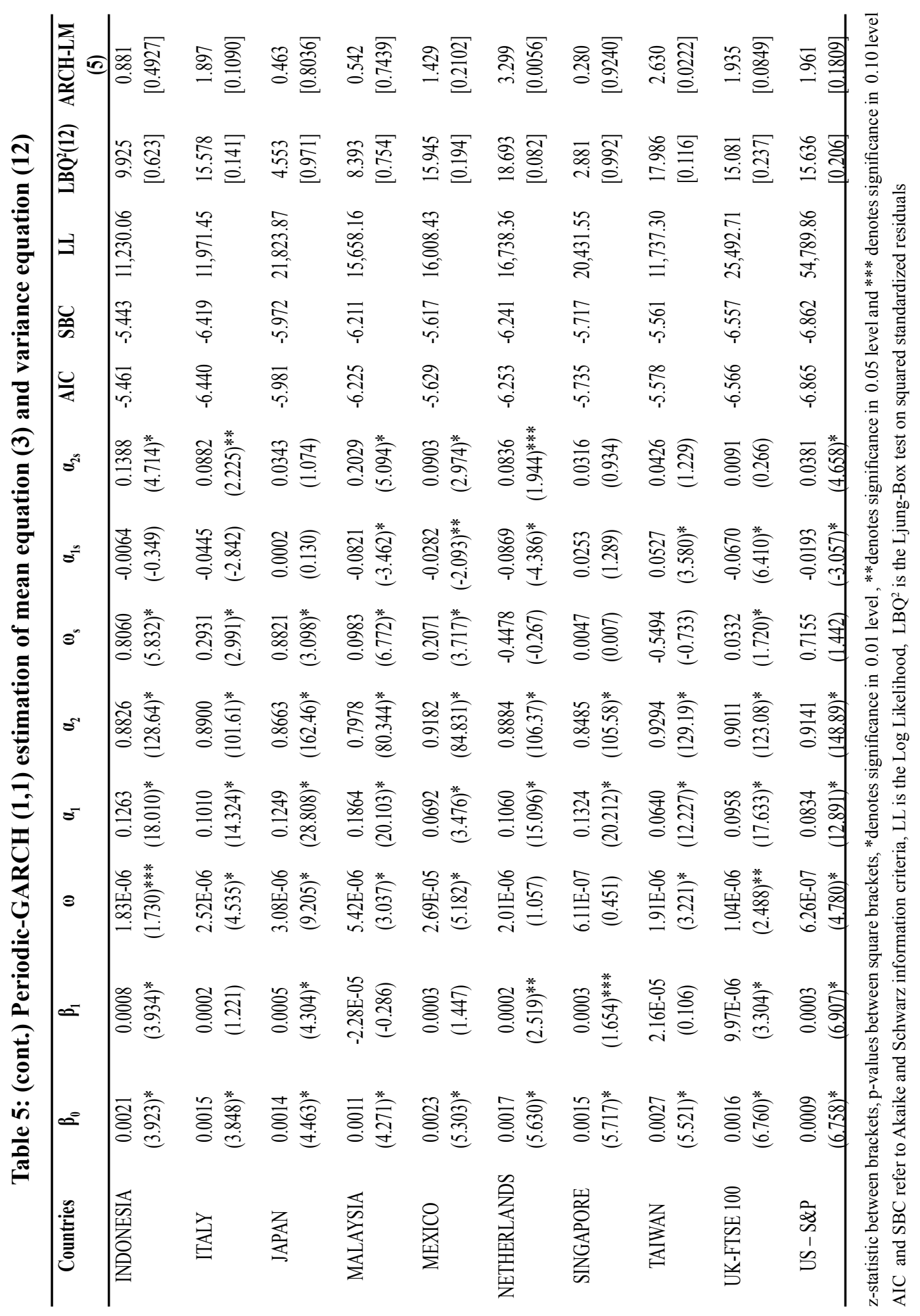




\section{Conclusions}

This study examined the turn of the month effect in 20 stock markets around the globe using GARCH and PGARCH models. The results show that the turn of the month effect is persistent in 19 out of 20 stock market indices during the whole period examined. Moreover, sub-sample periods have been explored too supporting the same concluding remarks. In addition, when the post financial crisis period sample 2010-2013 is excluded from the analysis, the turn of the month effect is present in all stock market indices.

The results of this study are consistent with earlier literature showing positive returns at the beginning of the month and zero returns in the latter part of the month (see e.g. Lakonishok and Smidt, 1988; Marquering et al., 2006). The paper provides several important implications for investors and academic researchers. For investors this paper gives useful information of the stock market behaviour during a calendar month and may provide some ideas for profitable trading strategies. More specifically, the results established that the stock market indices, examined in this study and regarding the turn of the month effect, are not efficient, with the exception of Australia. Thus, investors can improve their returns by timing their investment. However, given that the risks are also higher, extra returns may not be obtainable.

\section{Acknowledgements}

The author would like to thank two anonymous referees for their valuable comments and suggestions on the paper. Any remaining errors or omissions remain the responsibility of the author.

\section{References}

Aggarwal, A. and Tandon, K., 1994, 'Anomalies or illusions? Evidence from stock markets in eighteen countries', Journal of International Money and Finance, 13, pp. 83-106.

Ariel A. R., 1987, 'A monthly effect in stock returns', 'Journal of Financial Economics, 18, pp. 161-174.

Baillie, R. T. and Bollerslev, T., 1989, 'The Message in Daily Exchange Rates: A Conditional Variance Tale', Journal of Business and Economic Statistics, 7, pp. 297-305.

Baillie, R. T. and Bollerslev, T., 1991, 'IntraDay and Inter Market Volatility in Foreign Exchange Rates', Review of Economic Studies, 58, pp. 565-585.

Bollerslev, T., 1986, 'Generalized Autoregressive Conditional Heteroskedasticity, Journal of Econometrics, 3, pp. 307-327.

Bollerslev, T., Chou, R.Y. and Kroner, K.F., 1992, 'ARCH modelling in finance: A review of the theory and empirical evidence', Journal of Econometrics, 52, pp. 5-59.

Bollerslev T. and Ghysels, E., 1996, 'Periodic Autoregressive Conditional Heteroskedasticity', Journal of Business and Economic Statistics, 14, pp. 139-151. 
Bollerslev, T. and Hodrick, R.J., 1999, 'Financial Market Efficiency Tests', in Pesaran, M.H. and Wickens, M.R. Handbook of Applied Econometrics, Volume I: Macroeconomics. Blackwell Publishers, Oxford, pp. 415-458.

Box, G.E.P. and Pierce, D.A., 1970, 'Distribution of residual autocorrelations in autoregressive-integrated moving average time series models', Journal of American Statistical Association, 65, pp. 1509- 1526.

Cadsby, C.B. and Ratner, M., 1992, 'Turn -of - month and pre-holiday effects on stock returns: Some international evidence', Journal of Banking and Finance, 16, pp. 497509.

Çağl1, E.C. Mandac1, P.E. and Kahyaoğlu, H., 2011,'Volatility Shifts and Persistence in Variance: Evidence from the Sector Indices of Istanbul Stock Exchange', International Journal of Economic Sciences and Applied Research, 4, 3, pp. 119-140.

Dacorogna, M. M., Miiller, U . A., Nagler,R J., Olsen, R .B. and Pictet, O. V., 1993, 'A Geographical Model for the Daily and Weekly Seasonal Volatility in the Foreign Exchange Market', Journal of International Money and Finance, 12, pp. 413-438.

Dickey, D. A. and Fuller, W. A., 1979, 'Distribution of the Estimators for Autoregressive Time Series with a Unit Root', Journal of the American Statistical Association, 74, 366, pp. 427-431.

Engle, R.F., 1982, 'Autoregressive Conditional Heteroscedasticity with Estimates of the Variance of United Kingdom Inflation', Econometrica, 50, 4, pp. 987-1007.

Fama, E.F., 1970, 'Efficient capital markets: A review of theory \& empirical work', Journal of Finance, 25, pp. 383-417.

French, K.R. and Roll, R., 1986, 'Stock Return Variances: The Arrival of Information and the Reaction of Traders', Journal of Financial Economics, 17, pp. 5-26.

Georgantopoulos, A.G.G. and Tsamis, A.D., 2013, 'The Istanbul Stock Exchange: Testing the Significance of Calendar Anomalies', 7th Annual Conference of the Hellenic Finance and Accounting Association, (12 - 13 December, 2008, Crete, Greece 09/2013).

Giovanis, E., 2009, 'Calendar Effects in Fifty-Five Stock Market Indices', Global Journal of Finance and Management, 1, 2, pp. 75-98.

Hansen, P.R. and Lunde, A., 2003, 'Testing the Significance of Calendar Effects', Working Paper No. 2003-03.

Harvey, C. R. and Huang R. D., 1991, 'Volatility in the Foreign Currency Futures Market', Review of Financial Studies, 4, pp. 543-569.

Haugen, R. and Jorion, P., 1996, 'The January effect: Still there after all these years', Financial Analysts Journal 52, pp. 27-31.

Jaffe, J. and Westerfield, R.W., 1989, 'Is there a monthly effect in stock market returns? Evidence from Foreign Countries', Journal of Banking and Finance, 13, pp. 237-244.

Kunkel, C. and Beyer, S., 2003, 'The turn-of-the-month effect still lives: the international evidence', International Review of Financial Analysis, 12, pp. 207-221.

Lakonishok J. and Smidt S., 1988, 'Are Seasonal Anomalies Real? A Ninety-Year Perspective', The Review of Financial Studies, 1, 4, pp. 403-425. 
Ljung, G.M. and Box, G.E.P., 1978, 'On a measure of lack of fit in time series models,' Biometrika, 65, pp. 297-303.

Marquering, W., Nisser, J. and Valla, T., 2006, 'Disappearing anomalies: a dynamic analysis of the persistence of anomalies', Applied Financial Economics, 16, pp. 291-302.

Martikainen T., Perttunen, J. and Puttonen, V., 1995, 'Finnish turn-of-the-month effects: Returns, volume, and implied volatility', The Journal of Futures Markets, 15, 6, pp. 605-615.

McConnell, J.J. and Xu, W., 2008, Equity Returns at the Turn of the Month', Financial Analysts Journal, 64, 2, pp. 49-64.

Miller, M., Modigliani, F., 1961, 'Dividend policy, growth, and the valuation of shares', Journal of Business, 34, pp. 411-433.

Nelson, D. B., 1991, 'Conditional Heteroskedasticity in Asset Returns: A New Approach', Econometrica, 59, 2, pp. 347-370.

Nikkinen J., Sahlstrom P. and Aijo J., 2007, 'Turn-of-the Month and Intramonth effect: Explanation from the important macroeconomic news announcements', The Journal of Futures Markets, 27, 2, pp. 105-126.

Sariannidis, N., Koskosas, I., Kartalis, N. and Konteos, G., 2009, 'Macroeconomic effects on D.J.S.I.-World Returns', International Journal of Economic Sciences and Applied Research, 2, 2, pp. 95-110.

Sariannidis, N., 2010, 'The Impact of Stock, Energy and Foreign Exchange Markets on the Sugar Market', International Journal of Economic Sciences and Applied Research, 3, 1, pp. 109-117.

Sharma, S., and Narayan, P.K., 2014, 'New evidence on turn-of-the-month effects', Journal of International Financial Markets, Institutions and Money, 29, pp. 92-108.

Srinivasan, P. and Ibrahim, P., 2012, 'Price Discovery and Asymmetric Volatility Spillovers in Indian Spot-Futures Gold Markets', International Journal of Economic Sciences and Applied Research, 5, 3, pp. 65-80.

Tonchev T. and Kim, T.H., 2004, 'Calendar effects in Eastern European financial markets: evidence from the Czech Republic, Slovakia and Slovenia', Applied Financial Economics'14, pp. 1035-1043.

Vazakidis, A. and Athianos, S., 2010, 'Do Dividend Announcements Affect The Stock Prices in The Greek Stock Market?' International Journal of Economic Sciences and Applied Research, 3, 2, pp. 57-77.

Wood, R .A., McInish, T.H. and Ord, J . K., 1985, ‘An Investigation of Transaction Data for NYSE Stocks', Journal of Finance, 40, 3, pp. 723-739.

Ziemba W.T., 1991, 'Japanese security market regularities Monthly, turn-of-the-month and year, holiday and golden week effects', Japan and the World Economy, 2, 3, pp. 119146.

Zwergel, B., 2014, 'On the exploitability of the turn-of-the-month effect-an international perspective', Applied Financial Economics, 20, pp. 911-922. 